\title{
Optical developments for silicon thin film solar cells in the substrate configuration
}

Thomas Soderstrom, Franz-Joseph Haug, Xavier Niquille, Oscar Cubero, Stéphanie Perregaux, and Christophe Ballif

IMT/UNINE, Rue A.-L. Breguet 2, Neuchâtel, 2000, Switzerland

\section{ABSTRACT}

In the nip or substrate configuration thin film silicon solar cells, the choice of front TCO contact is critical because there is a trade off between its transparency which influences the current in the solar cell and its conductivity which influences the series resistance. Here, we investigate the optical behavior of two different TCO front contacts, either a $70 \mathrm{~nm}$ thick, nominally flat ITO or a $2 \mu \mathrm{m}$ thick rough LPCVD ZnO. The back contact consists of LP-CVD $\mathrm{ZnO}$ with random texture. First we investigate the influence of the rough and flat front TCOs in $\mu \mathrm{c}-\mathrm{Si}: \mathrm{H}$ and a-Si:H solar cells. With the back contact geometries used in this work, the antireflection properties of ITO are effective at providing as much light trapping as the rough LP-CVD ZnO. In the second part, we demonstrate that total of 25 to $26 \mathrm{~mA} / \mathrm{cm}^{2}$ is achievable in nip micromorph tandem cells and show short circuit current up to $11.7 \mathrm{~mA} / \mathrm{cm}^{2}$ using an SIO based intermediate reflector.

\section{INTRODUCTION}

In the thin film silicon solar market, the substrate or nip configuration can be a competitive advantage because flexible non transparent substrate can be used [1]. Furthermore, roll to roll deposition techniques [2] can be applied. Several companies develop solar cells with initial efficiencies over $15 \%$ [3-5]. Here, we develop low temperature processes (below $200^{\circ} \mathrm{C}$ ) compatible with plastic substrates such as PEN or PET. Our primary goal is to increase the stabilized efficiency of thin film silicon solar cell in the substrate configuration by using textured substrates, tandem micromorph structures [6].

In the nip configuration, substrate texture is compulsory to increase the current in the thin film silicon solar cell while reducing cell thicknesses. This leads to reduced light induced degradation effect [7] and effective cycle time in production. For efficient light trapping, the substrate textures should be in the dimension range of the incoming light wavelength. The common substrate used by the industries is hot silver which provide elevated light trapping in the cells. Here, we develop LP-CVD $\mathrm{ZnO}$ on glass substrate and it can also be applied on plastic. In addition, we compare two transparent conductive oxide (TCO) candidates as front contact; the first one is a flat thin ITO layer and the second one is a rough thick ZnO LP-CVD.

First, we describe the difference between the TCOs by reflection and transmission measurements on glass substrate only. Then, we investigate the behavior of ITO and $\mathrm{ZnO}$ front contact on amorphous (a-Si:H) and microcrystalline $(\mu \mathrm{c}-\mathrm{Si}: \mathrm{H})$ solar cells. Optically the situation between thin a-Si:H $(200 \mathrm{~nm})$ absorber and a thick $(1 \mu \mathrm{m}) \mu \mathrm{c}-\mathrm{Si}: \mathrm{H}$ is different. First of all the optimum dimension of the substrate texture is different for the two types of cell because the light trapping region is increased toward the red part of the spectrum for $\mu \mathrm{c}-\mathrm{Si}: \mathrm{H}$. In the third part, we describe the possible routes to further enhance the short circuit current $\left(\mathrm{J}_{\mathrm{sc}}\right)$ in micromorph 
tandem cells. We propose to use a thicker absorber layer, a rougher substrate texture and a $\mathrm{SiO}_{\mathrm{x}}$ based intermediate reflector to match the current of the top and bottom cells.

\section{EXPERIMENTAL}

The transparent front electrodes are zinc oxide $(\mathrm{ZnO})$ deposited by low pressure chemical vapour deposition (LP-CVD) [8, 9] or indium tin oxide (ITO) deposited by DC sputtering at room temperature. The $\mathrm{ZnO}$ is doped with boron, its deposition conditions result in a textured surface with RMS of about $70 \mathrm{~nm}$ for standard $2 \mu \mathrm{m}$ thick layers and its sheet resistance is below $10 \mathrm{ohm}$ square. The ITO is deposited nominally flat, has a thickness of $70 \mathrm{~nm}$ to act as an antireflection layer on $\mathrm{Si}$ and has a sheet resistance of $30 \mathrm{ohm}$ square on glass. The total transmission (TT), diffuse transmission (DT), and total reflexion (TR) are measured with a photo-spectrometer, (Perkin Elmer lambda 900) with integration-sphere within the spectral range of $400 \mathrm{~nm}$ to $2000 \mathrm{~nm}$. The absorbance (A) is calculated from TT and TR with A=1-TT-TR. The measured structure in the spectrometer is TCO/glass. The $\mathrm{ZnO}$ is measured as grown and with $\mathrm{CH}_{2} \mathrm{I}_{2}$ which means that a thin film of index matching liquid di-iodomethane $\left(\mathrm{CH}_{2} \mathrm{I}_{2}\right)$ is added between the $\mathrm{ZnO}$ layer and a $0.7 \mathrm{~mm}$ thick AF45 glass. It removes the effect of the rough interfaces and interference fringes during transmission and reflectance measurements [10].

As substrates, we use glass coated with LP-CVD $\mathrm{ZnO}$ which develops pyramidal textures during the growth process. This texture provides high current for nip single a-Si:H solar cells [6] with feature size of typically $360 \mathrm{~nm}$ with root mean square (RMS) roughness of $70 \mathrm{~nm}$. The size of the LP-CVD $\mathrm{ZnO}$ can be also adapted for $\mu \mathrm{c}-\mathrm{Si}: \mathrm{H}$ solar cells by increasing the lateral dimension to $1 \mu \mathrm{m}$ and RMS to $150 \mathrm{~nm}$. Similar morphologies are used for pin cells in our laboratory [11]. In addition, a white paint is added at the back of the glass as back reflector.

The silicon films are deposited by plasma enhanced chemical vapour deposition, at very high excitation frequencies (VHF-PECVD, 50-150 MHz). The main gases for the deposition are silane $\left(\mathrm{SiH}_{4}\right)$, hydrogen $\left(\mathrm{H}_{2}\right)$, and methane $\left(\mathrm{CH}_{4}\right)$. Phosphine $\left(\mathrm{PH}_{3}\right)$ and trimethylboron $(\mathrm{TMB})$ are added for the $\mathrm{n}$ and $\mathrm{p}$ doped layers.

The current-voltage (IV) measurements are performed at $25^{\circ} \mathrm{C}$ under AM1.5g solar spectrum with a solar simulator (Wacom WXS-140S-10). From that IV curve the $\mathrm{V}_{\mathrm{oc}}$ and FF are obtained. The external quantum efficiency (EQE) is measured with a spectral response setup at short circuit condition except when something else is specified. The short circuit current-density $\left(\mathrm{J}_{\mathrm{sc}}\right)$ is calculated from the EQE by convolution with the AM $1.5 \mathrm{~g}$ solar spectrum and by integrating over the wavelength range. This method avoids uncertainties in the determination of the solar cell surface area.

\section{RESULTS AND DISCUSION}

\subsection{Rough LP-CVD ZnO on glass}

Figure 1 (left) shows interference effects in the TT, TR and A curves of the thin flat ITO on glass which are not apparent in the case of $\mathrm{ZnO}$ measured with the $\mathrm{CH}_{2} \mathrm{I}_{2}$ index matching. The 
absorbance of the $\mathrm{ZnO}$ measured with $\mathrm{CH}_{2} \mathrm{I}_{2}$ is below $2 \%$ and is similar to the absorbance of ITO. Thus, the difference between the two TCOs can be completely attributed to the structure of the two devices, i.e. flat thin against thick rough TCO. The rough interface of the $\mathrm{ZnO}$ leads to an increase of the absorbance (not shown here for the sake of clarity) and reflection, see Figure 1 (right). It is attributed to light trapping within the $2 \mu \mathrm{m}$ thick ZnO. Note that the Haze (H=DT/TT) is $90 \%$ at $400 \mathrm{~nm}$ but only $22 \%$ at $700 \mathrm{~nm}$. It means that for the wavelengths between 650 and $800 \mathrm{~nm}$, they are only slightly scattered by the rough TCO/air interface. However, This $\mathrm{TCO} /$ glass device does not give direct information on the optical behavior of the rough $\mathrm{TCO} / \mathrm{Si}$ interface in the solar cell because light trapping due to total internal reflection will not take place at this interface $\left(\mathrm{n}_{\mathrm{Si}}>\mathrm{n}_{\mathrm{TCO}}\right.$, which is different from $\mathrm{n}_{\mathrm{TCO}}>\mathrm{n}_{\text {glass }}$ in this test structure).
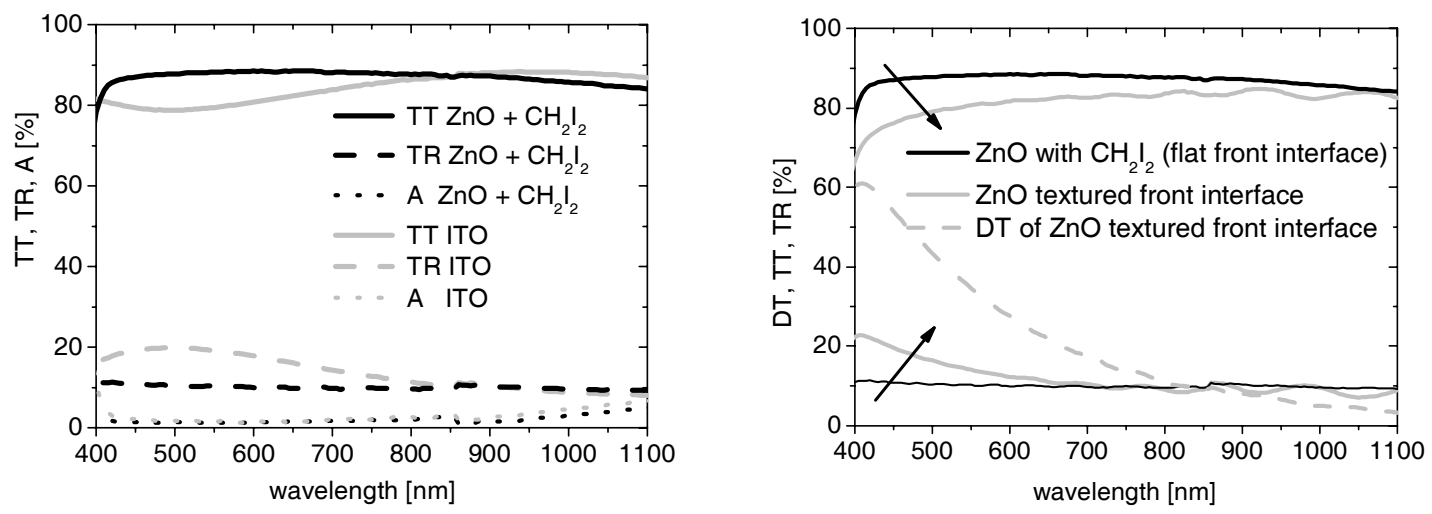

Figure 1: On the left, we compare the TT (plain line), TR (dashed line) and A (dotted line) of a flat $70 \mathrm{~nm}$ ITO (light grey), and a $2 \mu \mathrm{m} \mathrm{ZnO}$ (black) LP-CVD with $\mathrm{CH}_{2} \mathrm{I}_{2}$. On the right, we compare TT and TR for $2 \mu \mathrm{m}$ thick ZnO LP-CVD with flat (black) and rough (grey) air/ZnO interface.

\subsection{Rough $\mathrm{ZnO}$ and flat ITO in solar cells}

In Figure 2 and Table 1, we compare the same flat $70 \mathrm{~nm}$ ITO and the $2 \mu \mathrm{m}$ thick LP-CVD $\mathrm{ZnO}$ as front TCO in $270 \mathrm{~nm}$ a-Si:H and $1.1 \mu \mathrm{m}$ thick $\mu \mathrm{c}-\mathrm{Si}: \mathrm{H}$ solar cell. The cells are deposited on LP-CVD ZnO back contact on glass substrate. The lateral dimension of the back ZnO LPCVD has been adapted for the light scattering of both types of solar cells as described in section 2. A flat a-Si:H deposited on plastic substrate coated with $80 \mathrm{~nm}$ of silver and $60 \mathrm{~nm}$ of sputtered $\mathrm{ZnO}$ is added for reference. The results show that on textured substrates, there is advantage in using a flat ITO. Indeed, $\mathrm{J}_{\mathrm{sc}}$ is increased, relatively, by $3 \%$ for thin and thick absorber layers on textured substrates. The antireflection effect of the ITO yields increased spectral response close to $550 \mathrm{~nm}$ while the red part of the spectrum the response is similar for both TCOs on textured substrate. However, for a-Si:H on flat substrate the light trapping is increased with a rough LPCVD ZnO substrate compared to ITO. The LP-CVD ZnO even compensates the reflection losses at $550 \mathrm{~nm}$ by an increase of $\mathrm{EQE}$ between 600 and $750 \mathrm{~nm}$. 
Table 1: Comparison of the short circuit current density of a-Si:H and $\mu \mathrm{c}-\mathrm{Si}: \mathrm{H}$ solar cell with $\mathrm{ZnO}$ and ITO front contact

\begin{tabular}{lllll}
\hline $\mathrm{J}_{\mathrm{sc}}[\mathrm{mA} / \mathrm{cm} 2]$ & substrate & ZnO LP-CVD & ITO & $\Delta \mathrm{J}_{\mathrm{sc}}(\%)$ \\
\hline $\mathrm{a}-\mathrm{Si}: \mathrm{H}$ & Flat & 12.3 & 12.2 & 0 \\
$\mathrm{a}-\mathrm{Si}: \mathrm{H}$ & ZnO CVD & 14.7 & 15.1 & 3 \\
$\mu \mathrm{c}-\mathrm{Si}: \mathrm{H}$ & ZnO CVD & 21.0 & 21.6 & 3
\end{tabular}
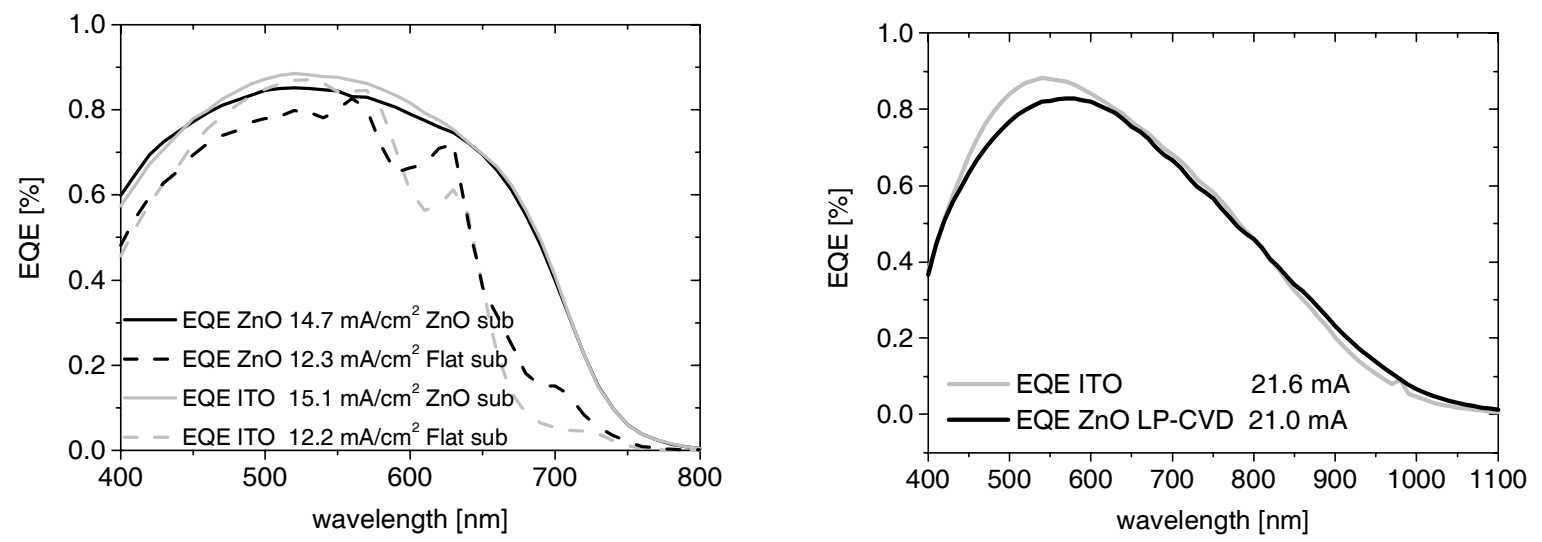

Figure 2: Left, comparison between flat ITO and rough LP-CVD ZnO front contact with a-Si:H solar cell on flat (dashed lines) and LP-CVD $\mathrm{ZnO}$ coated substrates (plain lines). Right, comparison between flat ITO and rough LP-CVD ZnO front contact with $\mu \mathrm{c}-\mathrm{Si}: \mathrm{H}$ solar cell on LP-CVD ZnO substrate wit large feature size.

\subsection{Micromorph tandem cells}

In this part, we report on micromorph solar cells contacted with the front ITO and the possible routes to further improve the tandems performances. The cell are deposited on a LPCVD ZnO substrate with large feature size of the pyramids. The thicknesses of the layers are 300 $\mathrm{nm}$ a-Si:H, and $1.2 \mu \mathrm{m} \mu \mathrm{c}-\mathrm{Si}: \mathrm{H}$, respectively, and $70 \mathrm{~nm}$ for the ITO front contact. The initial efficiency is $10.2 \%$ with $\mathrm{V}_{\mathrm{oc}}=1.33 \mathrm{~V}, \mathrm{~J}_{\mathrm{sc}}=11.3 \mathrm{~mA} / \mathrm{cm}^{2}$ and $\mathrm{FF}=68 \%$. For higher efficiency clearly the $\mathrm{J}_{\mathrm{sc}}$ needs to be increased. In fact best nip solar cell can reach total current up to 28 $\mathrm{mA} / \mathrm{cm}^{2}$ with ITO front contact [5].

We currently develop two strategies to further increase the efficiency of the micromorph cells. This development is carried out with LP-CVD front contact because this thick layer act as a protective coating for the Si films which facilitate the solar cell process and measurements by reducing shunting of the thin devices. First, we increase the total current of the tandem cells by increasing the thickness of the $\mu \mathrm{c}-\mathrm{Si}$ :H solar cell from $1.2 \mu \mathrm{m}$ to $2.5 \mu \mathrm{m}$, and second we use LPCVD ZnO substrate with structure that shows better light trapping performance [12]. In Figure 3 (left), we show that this increases the total current by $2.3 \mathrm{~mA} / \mathrm{cm}^{2}$ to a total of $25 \mathrm{~mA} / \mathrm{cm}^{2}$. Thus, with an ITO front contact, we expect to be able to achieve $26 \mathrm{~mA} / \mathrm{cm}^{2}$. But, it still does not increase the matched $\mathrm{J}_{\mathrm{sc}}$ of the tandem because so far all the increase of total current is in the 
bottom cell. The matching can not be achieved by increasing the top cell thicknesses without compromising the cell light induced stability [7]. Thus, we increase the top cell current by introducing an $\mathrm{SiO}$ based intermediated reflector (SOIR) between the top and bottom cell [13]. The $80 \mathrm{~nm}$ SOIR produces a refractive index difference with the silicon which increases the reflection from the solar cell. Figure 3 (right) shows that the top cell current can be increased by $1 \mathrm{~mA} / \mathrm{cm}^{2}$ and the bottom cell current is decreased by $2.4 \mathrm{~mA} / \mathrm{cm}^{2}$. Thus, the total current is decreased by $1.4 \mathrm{~mA} / \mathrm{cm}^{2}$ because part of the green light is in fact also reflected out of the solar cells. This value corresponds to observations with SOIRs in pin cells [13] which were however partially attributed to internal absorption. Thus, the performance of our intermediate reflector is not yet sufficient. We think that the refractive indexes of the IR can still be reduced below 2.1 which is our current status development. In fact this year in Fukuoka, M. Ichikawa reported a strong improvement of an IR material by achieving a refractive index of $n=1.6$ [14].
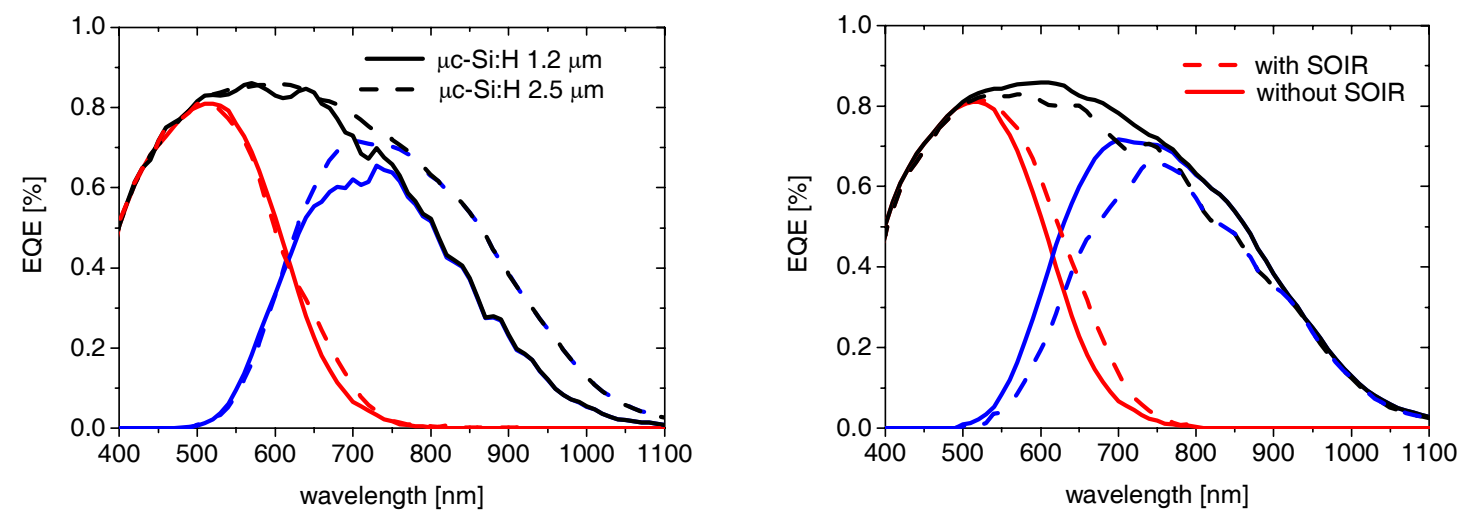

Figure 3: On the left, comparison of the EQE of micromorph cells with $1.2 \mu \mathrm{m} \mu \mathrm{c}-\mathrm{Si}: \mathrm{H}$ (full line) and thick $2.5 \mu \mathrm{m} \mu \mathrm{c}-\mathrm{Si}: \mathrm{H}$ bottom (dashed line) cells on LP-CVD $\mathrm{ZnO}$ substrate and with LP-CVD $\mathrm{ZnO}$ front contacts. On the right, we compare the EQE of micromorph cells with (dashed curve) and without SOIR (plain curve) on LP-CVD ZnO substrate and with ZnO LPCVD front contact.

Table 2: Comparison of the short circuit current density of micromorph with a $1.2 \mu \mathrm{m}$ and 2.5 $\mu \mathrm{m}$ thick microcrystalline absorber layer and comparison of $\mathrm{J}_{\mathrm{sc}}$ with and with SOIR between the top and bottom cell

\begin{tabular}{llll}
\hline Jsc $[\mathrm{mA} / \mathrm{cm} 2]$ & Top & Bottom & Total \\
\hline $1.2 \mu \mathrm{m} \mathrm{mc}-\mathrm{Si}$ & 10.6 & 12.0 & 22.6 \\
$2.5 \mu \mathrm{m} \mathrm{mc-Si}$ & 10.7 & 14.3 & 25.0 \\
$2.5 \mu \mathrm{m} \mathrm{mc}-\mathrm{Si}$ with SOIR & 11.7 & 11.9 & 23.6
\end{tabular}

\section{CONCLUSIONS}

Our study gives guidelines for front TCO optimization in the nip configuration taking into account different substrates for a-Si:H solar cells. In fact, on flat substrate the rough $\mathrm{ZnO}$ LP-CVD can achieve similar level of current density compare to thin ITO. In addition, this $\mathrm{ZnO}$ has the advantage to have lower sheet resistance compare to ITO and thus can be used in 
modules with an extended cells width and without silver grid. For textured substrate, we do not observe additional current gain due to additional light scattering in a:Si:H or $\mu c-\mathrm{Si}: \mathrm{H}$ and thus an ITO front contact is preferred thanks to the antireflection effects with the Si. Finally, we think that by combining an appropriate substrate texture, high quality flat ITO front contact and an adapted intermediate reflector which are all compatible with fabrication on low-T plastics we should be able to increase the stable efficiency of tandem devices above $10 \%$ in the near future.

\section{ACKNOWLEGEMENTS}

This work was performed within the EU-Project "Flexcellence" under contract 019948 and the Swiss Federal Energy Office (OFEN) under contract 101191. We thank J. Steinhauser for optical measurements.

\section{REFERENCES}

\section{References}

[1] A. Banerjee and S. Guha, Journal of Applied Physics 69 (1991) 1030.

[2] J. Bailat, V. Terrazzoni-Daudrix, J. Guillet, F. Freitas, X. Niquille, A. Shah, C. Ballif, T. Scharf, R. Morf, A. Hansen, D. Fischer, Y. Ziegler, and A. Closset, 20th European PVSEC (2005)

[3] Y. Ichikawa, S. Fujikake, H. Ohta, T. Sasaki, and H. Sakai, Photovoltaic Specialists Conference, 1991., Conference Record of the Twenty Second IEEE (1991) 1296.

[4] K. Saito, M. Sano, K. Matuda, T. Kondo, T. Nishimoto, K. Ogawa, and I. Kajita, Proc. 2nd World Conf. Vienna (1998) 351.

[5] B. Yan, G. Yue, J. M. Owens, J. Yang, and S. Guha, Conference Record of the 2006 IEEE 4th World Conference on Photovoltaic Energy Conversion (IEEE Cat. No. 06CH37747) (2006) 4 pp.

[6] T. Söderström, F.-J. Haug, V. Terrazzoni-Daudrix, X. Niquille, S. Perregeaux, M. Fahland, and C. Ballif, Proc. 22nd European PVSEC (2007)

[7] D. L. Staebler and C. R. Wronski, Applied Physics Letters 31 (1977) 292.

[8] S. Fay, U. Kroll, C. Bucher, E. Vallat-Sauvain, and A. Shah, Solar Energy Materials and Solar Cells 86 (2005) 385.

[9] J. Steinhauser, S. Faÿ, N. Oliveira, E. Vallat-Sauvain, and C. Ballif, Applied Physics Letters 90 (2007) 142107.

[10] J. Steinhauser, L. Feitknecht, S. Faÿ, R. Schlüchter, A. Shah, C. Ballif, J. Springer, L. Mullerova-Hodakova, A. Purkrt, A. Poruba, and M. Vanecek, Proceedings of the 20th EU Photovoltaic Solar Energy Conference (2005) pp. 1608.

[11] D. Dominé, J. Bailat, J. Steinhauser, A. Shah, and C. Ballif, in 4th World PVSEC, Hawaii, 2006, p. 1465.

[12] J. Bailat, D. Domine, R. Schluchter, J. Steinhauser, S. Fay, F. Freitas, C. Bucher, L. Feitknecht, X. Niquille, T. Tscharner, A. Shah, and C. Ballif, Conference Record of the 2006 IEEE 4th World Conference on Photovoltaic Energy Conversion (IEEE Cat. No. 06CH37747) (2006) 4 pp. 
[13] P. Buehlmann, J. Bailat, D. Domine, A. Billet, F. Meillaud, A. Feltrin, and C. Ballif, Applied Physics Letters 91 (2007) 143505.

[14] M. Ichikawa, T. Meguro, F. Sezaki, T. Kuchiyama, K. Yoshikawa, and K. Yamamoto, Technical Digest of the International PVSEC-17, Fukuoka, Japan, 2007 